Article

\title{
Pervasive Anxiety about Islam: A Critical Reading of Contemporary 'Clash' Literature
}

\section{Meena Sharify-Funk}

Department of Religion and Culture, Wilfrid Laurier University, 75 University Ave., Waterloo, ON N2L 3C5, Canada; E-Mail: msharifyfunk@wlu.ca

Received: 8 July 2013; in revised form: 17 September 2013 / Accepted: 18 September 2013 /

Published: 25 September 2013

\begin{abstract}
This article analyzes and critiques North American and European "clash literature" - a genre of post-9/11 writings that popularize elements of Samuel Huntington's "clash of civilizations" thesis, with particular reference to putative threats posed to Western civilization by Islam and Muslims. Attention is given to a series of salient themes used by multiple texts and authors, in a manner that creates an overarching narrative of Western moral superiority vis-à-vis a monolithic, authoritarian, and misogynistic Islamic culture; betrayal of Western culture by "politically correct" intellectual elites wedded to ideas of multicultural accommodation; and a cascading threat posed by the rapid influx of unassimilable Muslim immigrants who are poised to mount a demographic takeover of Europe and possibly America as well. The content of clash texts is then analyzed and evaluated in light of its detachment from relevant scholarship, its reliance on highly essentialized identity constructs, its use of demographic extrapolations and alarming anecdotes, and its stark rejection of contemporary pluralism. The article concludes with reflections on how scholars might respond to the identity insecurities revealed by clash literature as they seek to advance alternative narratives based on values of dialogue and coexistence.
\end{abstract}

Keywords: clash of civilizations; Islamophobia; Muslim immigration and integration; Islam and the West 


\section{Introduction}

Since Samuel Huntington posited the now infamous "Clash of Civilizations" theory in a 1993 essay published in the journal Foreign Affairs, much academic controversy has flared around his assertion that cultural and religious differences will become the main source of international conflict in the post-Cold War era. Although Huntington's thesis has been frequently criticized by a broad spectrum of academics for its extremely broad-brush approach to conflict analysis and its vulnerability to manipulation as a conflict-intensifying cliché, the events of September 11, 2001 catapulted his ideas beyond the academy and into the heart of contemporary discourse. His predictions that civilizational conflicts would be especially prevalent between Muslims and non-Muslims received particular attention, as did his effort to shift discussion of international affairs from the ideological geopolitics of the Cold War to resurgent religio-cultural identities rooted deep in history. With statements on political geography such as, "Europe ends where Western Christianity ends and Islam and Orthodoxy begin," Huntington proposed that religiously based civilizations constitute the largest meaningful framework for human loyalty, and emphasized the frailty of political projects with broader scope and ambition, from the European Union to the United Nations. Huntington also arguably contributed to an intellectual atmosphere within which many less disciplined writers felt greater freedom to write their own manifestos linking contemporary concerns about terrorism to a primordial struggle between "Islam and the West".

While most academics ignore writings that might be construed as combative popularizations of Huntington's clash theory, the proliferation of exactly this variety of clash literature since September 11, 2001 constitutes a phenomenon worthy of investigation and analysis. This broader clash literature, which proclaims an intent to break the shackles of "political correctness" and tell the truth about Islam and the West, contains many volumes which have risen to best-seller heights and is deservedly controversial. In content as well as tone it is decidedly alarmist and insistently polarizing. Leaving behind the subtler forms of orientalist derogation critiqued by Edward Said in his influential thesis on the subject [1], the new clash literature represents Islam and the $\mathrm{West}^{1}$ as irreconcilable entities locked into ideological and sometimes actual warfare for decades if not centuries. Dismissing dialogue and relying on strident "us vs. them" rhetoric, the literature actively seeks to interfere with the development of relations between Muslims and non-Muslims. Though produced by authors of varied backgrounds, the written products display striking consistencies in core premises and ultimate conclusions, as "ex-Muslims" who generalize from negative personal experiences find common cause with atheists warning against religious resurgence as well as with theologians who worry that apocalyptic demographics will displace their religious heritage once and for all.

Given the astronomically higher sales of such books (e.g., Infidel and Surrender and America Alone) when compared to writings espousing dialogue and coexistence, themes from the clash literature have undeniably infiltrated the public imagination in Europe and North America, amplifying negative perceptions of Islam and Muslims and reinforcing popular anxieties. Though emphasis varies

1 "The West" as defined by clash literature is implying both Europe and North America. However, some books specifically focus on Europe with America in the background. For this article, it is important to note that the influence of clash literature whether focusing on Europe and/or America extends from North America to Europe (especially since most of the authors are originally from North America). 
somewhat across texts and authors, books from the clash literature consistently encourage a culture of suspicion within which Islam and Muslims constitute a threat to Western societies. Islam is portrayed as the religious heritage of a dysfunctional and misogynist "tribal" society that prevents Muslims from adapting to modern settings and leaves all Muslims vulnerable to indoctrination with radical ideology. Because Islam is incompatible with cultural and political liberalism, Muslim immigrants cannot be integrated into Western culture, and "ghettoization" of Muslims in Western societies is self-inflicted rather than driven by adverse social, economic, and political factors.

While acknowledging differences in emphasis and focus within the clash literature, this article will analyze and critique prominent shared themes found throughout these books. Particular attention will be given to what might be described as the overarching narrative that informs the clash literature. According to this narrative, "the West" and Western liberalism embody humanity's highest achievements, which are manifest in societies, structures, and norms that underscore individual freedom and political secularism. Rather than push Muslims and Muslim societies to adopt these ideals, however, Western elites have lost confidence in the fundamentals of their own traditions and succumbed to patronizing forms of "good will" and practices of political correctness, epitomized by policies that promote multiculturalism and ignore the pathologies of immigrant cultures. By opening the gates of society to large-scale Muslim immigration and failing to require assimilation, this approach has put Western and especially European societies on a path that will eventually lead to the demise of Western culture. Demographic factors linked to differential marriage and fertility rates will now lead to an inexorable decline or "slow suicide" of Western civilization as we know it. The only way to correct this decline and avoid a "last days" scenario, these authors suggest, is to assertively condemn Islamic culture and promote women's emancipation within Muslim communities.

After identifying and illustrating key themes of this narrative within multiple clash texts, analytical attention will be directed not so much to specific exaggerations and distortions inherent in this literature as to the overarching mode of argument and the way in which key themes are intended to speak to North American and European readers. Although there is no denying that many purveyors of clash literature have political motives [2-4] and are reproducing, in exaggerated form, classic tropes of orientalism [5] that run counter to much empirical evidence [6], the clash literature is also worth probing for what it reveals about contemporary "Western" identity insecurities. Clash authors rely heavily on pessimistic extrapolations and cherry-picked facts in ways that serve to advance a dehumanizing image of Islam and Muslims, all the while articulating a clear intent to sharpen polarization and dispel hope that relational engagement might transform or mitigate conflict. The fact that tendentious arguments purveying dehumanized enemy images have led to remarkable book sales should arouse concern. ${ }^{2}$ By taking contemporary identity insecurities seriously but not succumbing to discourse rooted in dualism, blame, or scapegoating, scholars who pause to reflect on the meaning of the clash literature have the potential expand academic as well as popular conversations. The very appeal of the clash literature points to a profound need for new arguments and visions - for accessible but not unsubstantial literatures that seek to stretch human imagination beyond the simplistic dichotomies and the reactionary impulses that have come to define the "post-9/11" era.

2 For commentary on the significance of dehumanization and enemy images with the context of identity conflict, see [7-9]. 


\section{The West as a Threatened Savior: Western Liberalism vs. Islamic Authoritarianism}

At the core of the new clash literature is an attempt to define Western values and identity in relation to - and at the expense of - a threatening Islamic "other". "The West" is portrayed as a fundamentally sound civilization, embodying the peak of idealism and human achievement, whereas Islam is characterized as a confounding diseased tradition that is rotten to the core. ${ }^{3}$ Whereas the West is inherently benign, peaceful (there is no critique of colonialism and the imperial era), and focused on the liberation of human potential, Islam is equated with violence, an irrational drive towards world domination, and an absence of human liberty. For each attributed virtue or positive quality of the West, Islam provides an idealized foil or contrast. The West appears without the taint of historical errors or injustices, while Islam is essentialized as the West's antithesis, or shadow.

Robert Spencer, a prominent conservative blogger who has been officially banned from Britain for his provocative advocacy against Islam [12], articulates this approach to contrasting Islam with the West in quite vivid terms. In his Religion of Peace?: Why Christianity Is and Islam Isn't, Spencer argues that the core of Islam, including Sharia laws, is built on the fundamentals of violence and domination. He therefore urges all other religious orders to align against this "common enemy" of "Islamic supremacy" ([13], p. 204). In making such arguments, Spencer and most other clash authors establish a fundamental distinction between their own discourse and arguments made in conventional post-9/11 anti-terrorism discourse. Whereas the former asserts directly that Islam is fundamentally flawed in ways that predispose followers toward violence, the latter differentiates between extremist and mainstream positions within the Muslim community. ${ }^{4}$

A related theme of clash literature is that, despite the obvious hostility of Islam and Muslims, most Westerners are unaware of the gathering danger posed by Islamic infiltration of European and North American societies. As Bruce Bawer argues in Surrender: Appeasing Islam, Sacrificing Freedom, "We in the West are living in the midst of a jihad, and most of us don't even realize it..." ([15], p. 3). Bawer proposes that because violence and Islamic supremacy are intrinsic to the Islamic faith, Muslims living in the West are necessarily engaged in jihad to dominate Westerners and deprive them of individual freedom. To lend credence to this position, he utilizes individual stories of trauma and pain in which Islam can be identified as the perpetrating factor.

3 It is interesting to note that Muslim dissident reformist literature, which utilizes clash discursive tendencies, differs on this point. Such literature inherently advocates that Islam is not innately evil rather, Islam is worth saving and reform is essential for any transformation to occur. Much of this literature claims to be a "wake-up" call for Muslims. One prominent example in this literature is Asra Nomani's Standing Alone in Mecca: An American Woman's Struggle for the Soul of Islam [10]. For a comparison of this literature to the clash literature analyzed in this article please see my forthcoming manuscript, Controversies, Clichés, and Conversations: Islam, Muslim Women, and the Negotiation of Identity in Contemporary North America [11].

4 Spencer is a charismatic speaker and author who received his Masters in Religious Studies at the University of North Carolina. He has published twelve books specifically on the Islamic threat to Western society, and is currently the director of Jihad Watch, an Internet blog designed to monitor and report subversive Islamic theology and action. He also has participated in numerous seminars for American military groups (i.e., United States Central Command, United States Army Command and General Staff College, the U.S. Army's Asymmetric Warfare Group, the FBI, the Joint Terrorism Task Force, and the U.S. Intelligence community) [14]. 
Like many fellow authors within the clash literature, Bawer draws heavily on the writings of Ayaan Hirsi Ali, a best-selling Muslim "dissident" and controversial former Dutch parliamentarian who now resides in the United States. Hirsi Ali attributes much hardship and suffering to her fundamentalist upbringing as a Somali migrant whose family settled in Kenya. Her early Islamic education was heavily influenced by Wahhabi or puritanical forms of religious interpretation, and she extrapolates from examples derived from her own experience of conservatism within a particular branch of Muslim culture to arrive at negative conclusions concerning the whole of Islam. She describes her Dutch education in Enlightenment thinking as a liberating force in her own life, particularly after the violent incidents of September 11, 2001. Having faced deeply threatening reactions to her personal liberation from Islamic conservatism and her growing political activism, she generalizes about Muslim immigrants in Western countries and argues that they pose a grave threat to the social and political fabric of these countries. Western institutions and individuals, she asserts, need to stop supporting the preservation of foreign cultural values, particularly those derived from Muslim cultures. Instead of multiculturalism, the emphasis should be put on replacing Islamic ways of thinking and living with alternative values derived from the European Enlightenment: democracy, individual freedom, and gender equality. Once again, Islam and the West are presented as antithetical wholes with diametrically opposed ideals and values. Where Islam suppresses the individual and subjugates women, the West liberates. Where Islam teaches dogmatism, authoritarianism, and ideological closure, Western rationalism promotes freedom of thought, choice, and opportunity.

Personal narratives of oppression and liberation from figures such as Ayaan Hirsi Ali as depicted in her best-selling books (i.e., Infidel and Nomad) are central to clash literature, providing personal traumatic testimonials from disaffected Muslims to back up larger, more abstract arguments. The following passage from Bawer is illustrative:

In response to the common criticism that Hirsi Ali is inappropriately disrespectful toward Muslims: "Why should anybody be expected to respect a religion that demands his or her submission, subordination, or even execution?" ... As for 'insulting'-well, exactly who is insulting who? It isn't as if European Christians and Jews are running around raping Muslim women, defacing Muslim cemeteries, shooting bullets into the facades of Muslim houses of worship, and tormenting Muslim children in school ([15], p. 139).

Treating those who threatened Hirsi Ali for her advocacy against Islam and Muslims as the authentic representatives of the religion itself, Bawer does not hesitate to hold Islam as such responsible for the negative dynamics of her particular life experiences. Having ascribed guilt to Islam in general, he then asserts the innocence of Western and specifically European parties vis-à-vis Muslims. Leaving aside the events of the former Yugoslavia during the 1990s, when behaviours such as those described by Bawer did in fact take place, the mode of argument manifests strong elements of provocation, and can be understood to imply that the Islamic religion begets offences that are presumably alien to the Christian and Jewish experiences. Insofar as historical analysis reveals that abusive behaviours in the name of Christianity and Judaism have occurred in a manner not unlike those attributed to Islam, a discerning reader could easily receive the impression that the eagerness to generalize darkly about Islam and Muslims is at least in part driven by a psychology of projection and a desire to refuse confrontation with past ghosts of the Western experience, including "religious" wars and various ways in which individual and women's rights were denied or suppressed. 
This inability to articulate the complexity of the Western experience, and the manner in which the story of "the West" (insofar as one can be told) is very much a struggle for "Western" solutions to "Western" problems, is intimately linked to attitudes toward Islam that some critics would describe as neocolonial. If the West represents the fulfillment of humane values, and if it is itself devoid of a shadow side, why should the West not also be the primary vehicle for saving benighted societies that lack indigenous virtues and credible wellsprings of internal reform? Such thinking about Western superiority and the need for Western victory in a cultural war with Islam is an explicit theme in Hirsi Ali's writings as well as in the clash literature more generally. Throughout, there is an equation of the West with freedom and Islam with incarceration. The following passage from Hirsi Ali is illustrative:

When I'm told to be careful not to impose western values on people who don't want them, I beg to differ. I was not born in the west and I did not grow up in the west. But the delight of being able once I came to the west to let my imagination run free, the pleasure of choosing whom I want to associate with, the joy of reading what I want, and the thrill of being in control of my life - in short, my freedom - is something I feel immensely as I manage to extricate myself from the shackles and obstacles that my bloodline and my religion imposed ([16], p. 242).

In Hirsi Ali's view, the Western story of human emancipation through reason and education can unshackle Muslim societies just as it liberated her own imagination. She calls upon schools and universities to "openly challenge the beliefs of Muslim children and their parents" and help them to cast off Muslim "self-imposed blinkers" ([16], p. xix). The West holds an antidote to superstition, poverty, and tyranny, and should vigorously seek to win a cultural war against Islam: "There is already a clash, and we are in some sense already a war. That western civilization is superior is not simply my opinion but a reality I have experienced and continue to appreciate everyday. I assume that the west will win. The question is how" ([16], p. 245). Such arguments articulate quite succinctly key elements of the worldview present within the clash literature: two civilizations are locked in struggle, one based on reason and the other rooted in religious law and stifling superstitions. The superior civilization must confidently pursue victory over the lesser civilization, but to defend its gains and to liberate those shackled by centuries of religious obscurantism.

\section{The Denial of Muslim Moderation}

To maintain this vision, writers of clash literature need to persuade readers that Muslims are far more alike than unalike, and that they cannot be trusted either to harmonize with Western social norms or implement their own religious reformation. Many are quite blunt in asserting that, though Muslims may differ somewhat in the means that they choose, there are not significant differences between the goals of mainstream Muslims and those of terrorists. Mark Steyn, author of the 2006 New York Times bestseller, America Alone: The End of the World as We Know It, states that, "A large majority of Western Muslims support almost all the terrorist's strategic goals." He substantiates this by citing a poll in which "over 60 percent of British Muslims" articulated a desire to "live under shari'a in the United Kingdom" ([17], p. 76). Though this is certainly an unsettling statistic for many non-Muslims, its significance is less obvious than Steyn implies, given that Muslims differ quite profoundly in their understandings of sharia, and a desire among many to make their personal lives (particularly matters 
such as marriage, intimate relations, funerals, and divorce) compliant with traditional Islamic norms need not necessarily imply a totalizing theocratic threat to the Western way of life. Like statistics concerning the number of Americans who question evolutionary theory or who believe end times are imminent, the number cited by Steyn does not immediately lend itself to a definitive, let alone alarming, interpretation. Sounding an alarm is, however, a quite definite intention behind works like America Alone. Steyn's book addresses the relationship between America, Europe, and Islam. Writing within the overall context of the global war on terror, Steyn places particular weight on recent demographic statistics signalling population trends in Muslim and non-Muslim countries: Muslim immigration, birth rates, fertility rates, and marriage rates. He darky raises the prospect that Europe will fall to Muslim domination, leaving only America to uphold Western values in the face of a Muslim opposition that lacks true moderates. The text, incidentally, was recommended by former U.S. president George W. Bush to his staff. ${ }^{5}$

For Steyn and other clash authors, the West has no trustworthy allies within the Muslim world, except for those who place themselves on or beyond the outer margins of Islamic faith and belief. Creating a vision within which an authentic Muslim cannot truly be moderate, they portray Islam itself as an extreme religion that prevents assimilation and compromise. Those who seek to paint a different picture of an Islam that is dynamic and flexible or endowed with positive values are discounted as "apologists."

A writer known as Ibn Warraq in his Why I am Not a Muslim, himself reputedly a former Muslim, dismisses those who represent Islam positively and equates Islam with the worst events in Muslim history, which are presumably far worse in magnitude than persecutions organized by followers of other religions.

Apologists of Islam still insist on perpetuating the myth of an Islam that accorded equality to her non-Muslim subjects: they talk of a time when all the various religious communities lived in perfect harmony in the Islamic lands. The same apologists minimize, or even excuse, the persecution, the discrimination, the forced conversions, the massacres, and the destruction of the churches, synagogues, fire temples, and other places of worship ([18], p. 214).

For Ibn Warraq, as for other clash authors, Islam is an exception in the domain of religions, intrinsically intolerant and aggressive. Implicitly, Muslims who insist otherwise are either being dishonest or else they are not truly Muslims.

Many clash authors appear to favour the former interpretation, that so-called "moderate Muslims" are actually hiding the extent of their support for radical Islamic ends. Rhetorically, Steyn attacks the credibility of his intellectual opponents by associating their views with those of terrorists. The language is inflammatory, and seeks to discredit all Western Muslim commentators as potential enemies within: "Given the very few degrees of separation between very prominent Western Muslims - ambassadors, princes, professors - and the terrorists, it seems likely that many prominent figures in these parties will be supportive of terrorists ends" ([17], p. 204). Bawer uses a similar

5 It is important to note that Steyn is a Canadian-born writer, political commentator and cultural critic. Steyn often writes articles for the most popular Canadian journal, Macleans. In 2007, the Canadian Islamic Congress filed human rights complaints against Maclean's Magazine for publishing eighteen "Islamophobic" articles by Steyn to the Canadian Human Rights Commission. The Commission dismissed the complaints in June 2008. 
approach to characterize his adversaries, suggesting that even the most "assimilated" or liberal of Muslims living in the West harbour elements of the Islamic worldview, which, by their nature of being Islamic, clash irreconcilably with those of the secular Western worldview. "No, there's no guarantee," states Bawer, "that western Muslims, in meaningful numbers, will ever openly and actively champion freedom and defy jihadists; to do so, after all, is alien to every value with which many of them were raised" ([15], p. 276).

Hirsi Ali similarly discounts the notion of Muslim moderation, focusing particularly on what she sees as the inherent contradictions of this position. Because Islam, in her view, is scripturally wired for immoderate beliefs, an authentic Muslim cannot truly be "moderate" or "modern." Writing as if a large number of moderate, educated, and religiously dedicated interpreters of Islam did not exist, Hirsi Ali proposes that Muslim insistence on basic articles of faith such as the inspired nature of the Qur'an precludes intelligent reflection on the meaning of scripture for today:

A moderate Muslim does not question Muhammad's actions or reject or revise parts of the Quran. A moderate Muslim may not practice Islam in the way that a fundamentalist Muslim does-veiling, for example, or refusing to shake a woman's hand — but both the fundamentalists and the so-called moderates agree on the authenticity and truthfulness and the value of Muslim scripture ([16], p. 195).

In making this argument, Hirsi Ali chooses to ignore the vast differences in position taken by Muslims of differing ideological and interpretive dispositions, and demonstrates a lack of awareness that even so-called fundamentalists interpret their religious sources.

Significantly, the pronouncements of clash authors are themselves based on an interpretation of Islam - an interpretation that equates religious extremism with religious authenticity. Robert Spencer's proposal for a religious alliance against Muslims to defend the West reveals this quite clearly:

Islam seeks the conversion, subjugation, or death of not only Christians but also all-non-Muslims. Thus it is imperative that all the victims or potential victims of Islamic jihad-Christians, Jews, Buddhists, Hindus, atheists, secular Muslims, and all others-recognize that...we must all hang together, or we shall indeed hang separately ([14], p. 10).

For Spencer, the beliefs of the most extreme and inflexible Muslims are to be taken as normative, while the beliefs of others are discounted and treated as either insincere or insignificant. Islam, he proposes, cannot accommodate moderation, and must be resisted.

Some authors of clash literature affect a less strident and more nuanced attitude toward Islam, while conveying a generally negative evaluation of the religion and its adherents. Christopher Caldwell, Senior Editor at The Weekly Standard and a regular contributor to the Financial Times, casts serious doubt on the Muslim capacity for adaptation, and points to disproportionate incarceration rates among European Muslims ([19], p. 135). In his popular book, Reflections on the Revolution in Europe, skepticism about Islam is conveyed more indirectly and with greater subtlety:

Reaching out to so-called "moderate Muslims" is the cornerstone of European strategy against terrorism. Moderate Muslims are the people who can be trusted not to "distort Islam", or at least to distort it is a positive way-by building a "European islam" that can interact with the continent's political institutions without breaking them ([19], p. 283). 
By inserting the adjective "so-called" before the term "moderate Muslims" and using a lowercase letter for "European islam," Caldwell casts doubt on the authenticity of accommodating Muslim responses to Western culture and institutions. In the clash literature, the mark of authenticity is applied to forms of Islamic practice that appear most incompatible with the idealized Western model with which they are compared.

\section{Demise of the West: Muslim Demographics and the Loss of Faith}

Demographics are a salient theme in a variety of clash texts, and one of the primary areas in which the authors perceive the West to be vulnerable. Drawing upon a variety of trajectories, projections, and conjectures, the authors paint a picture in which Muslims gradually overcome their non-Muslim counterparts, particularly in Europe, and achieve by high immigration levels and birthrates what they could not accomplish by military means: a "Muslim Takeover" of Europe. They accomplish this "Takeover" with the complicity of liberal elites attached to welfare and multicultural policies that impede assimilation and foster an atmosphere of political correctness that stifles protest.

Concern about new classes of immigrants who cannot be assimilated is by no means a new phenomenon. In the United States, large-scale immigration of Catholics from Ireland and southern Europe generated great anxiety in the late $19^{\text {th }}$ and early $20^{\text {th }}$ centuries, leading to arguments about fertility rates and questionable religious loyalties that parallel those made about contemporary Muslim immigration to Western contexts. ${ }^{6}$ The validity of such comparisons is not obvious to clash authors, however, who view the opening of immigration to Muslims through a dark lens.

In Decline and Fall: Europe's Slow-Motion Suicide, Bruce Thornton goes so far as to describe Europe's accommodation of a Muslim presence as "suicide by immigration"- not just resignation in the face of an "invasion" ([20], p. 80), but "a complete capitulation and betrayal of Western civilization" ([20], p. 80). This betrayal reveals the extent to which "cultural toxins" have infected the West since WWII, especially "fashionable self-loathing guilt over supposed Western crimes like racism, imperialism, colonialism.” This guilt weakens Europeans and emboldens “invaders” ([20], p. 80).

Christopher Caldwell's language is less pointed, but advances similar undertones of Muslim invasion. When Europeans opened their doors to mass immigration in the wake of World War II, they began a monumental experiment without any consideration of the long-term consequences or "hidden costs". As a result, the face of Europe is changing:

Muslims now either dominate or vie for domination of certain important European cities.... Such places may, as immigration continues and the voting power and political savvy of the Muslims already there increases, take on an increasingly Muslim character ([19], p. 118).

As soon as it became obvious that certain immigrants proposed to establish foreign cultures on European lands, immigration - and Muslim immigration a fortiori - appeared in a different light. It appeared in the light of a project to claim territory ([19], p. 132).

Using government statistics, social surveys, think-tank reports, novels, and newspapers in eight different languages, Caldwell argues that changes are underway that will fundamentally change the

6 For more about this comparison see reference 6. 
character of the European experience, providing lessons in failed government policies that have increased the challenge of merging newcomers who were already resistant to assimilation into the continent's established cultures and values.

Walter Laqueur's The Last Days of Europe: Epitaph for an Old Continent explores similar themes, but with added emphasis on the unplanned and uncontrolled nature of Muslim immigration, as well as on what he regards as the dysfunctional impact of welfare policies. Like Caldwell and other authors, he bemoans the fact that Europe's once predominant place in the world is a thing of the past. Continued decline, he suggests, appears inevitable; changes in the European landscape associated with the large influx of Muslim immigrants are both a consequence of this decline and a major contributing factor. ${ }^{7}$

Laqueur points out that the first wave of immigration had much to do with the dissolution of Empires (e.g., West Indians, Pakistanis, Indians from India, and Indians from Uganda going to the United Kingdom; North Africans migrating to France) and was generally assumed to be a temporary phenomenon regulated by work permits. Many of these immigrants, however, managed to stay on legally or illegally, "and the host governments were not willing to enforce the law against those who broke it." Thus, major foreign communities were developing in Europe at the same time as the oil crisis of 1973, which reinforced trends toward high unemployment ([21], pp. 34-35). The growth of Asian, African, and Middle Eastern immigrant communities, then, had less to do with genuine opportunity than with high birthrates, success in bringing dependents to Europe (legally or illegally), the transformation of illegal immigration into an organized business, and the proliferation of asylum seekers fleeing imprisonment or political turmoil. To underscore the rapid pace of population growth and its transformative impact, Laqueur cites a variety of data that indicates the doubling and tripling of Muslim communities across Europe since 1980s-2006 ([21], pp. 36-37).

In Laqueur's view, these changes bode ill for the future of Europe, for a variety of reasons. In addition to the fact that many immigrants have been unable to find steady and gainful employment, European countries were not well prepared to absorb large-scale immigration by foreigners emanating from wholly different cultures ([21], p. 170). Though Laqueur does not go so far as Bawer in emphasizing undesirable values held by new immigrants who were not prepared to play by established rules and respect European institutions, ${ }^{8}$ he does suggest that European countries were to some degree taken advantage of by immigrants whose primary motivations were economic, and whose ranks included a criminal element:

...[E]ven though the majority of these immigrants, probably the great majority, were not political refugees but economic immigrants in search of a better life for themselves and their children. Among the political asylum seekers there were islamists or even terrorists who were indeed in danger of being arrested in their native countries, but for reasons that had nothing to do with the struggle for democracy and freedom....also asylum seekers were criminals and came to establish criminal gangs ([21], p. 35).

In permitting large-scale immigration, therefore, European nations allowed the infiltration of Islamists, terrorists, and others who were in danger of being arrested in their own countries. The latter

7 Other factors in Europe's decline include the stalling of the movement toward European unity and the crisis of the welfare state, as well as a European crisis in self-confidence that is both a contributor as well as a result of these factors.

8 Bawer states "Most come from poor villages in underdeveloped countries with high levels of corruption-a background that tends to breed cynicism, duplicity, and an exceptional skill at manipulating the system" ([1], p. 30). 
established criminal gangs specializing in the drug trade, prostitution, car, and other illegal activities in their new home countries. A significant proportion of the immigrants came to depend on European welfare services "from the day of their arrival." State authorities should have instead directed them to "productive labour" ([21], p. 172). Laqueur finds it particularly upsetting that some Muslim immigrant religious leaders were inclined to incite their followers "against the decadent and sinful Western way of life" and believes these figures should have been deported. "They should have been expected to behave in accordance with the law of the land and the values and prevailing norms. If these laws and norms were not according to their convictions, they would have been free to leave." ([21], p. 172).

Steyn's treatment of this subject echoes that of other clash authors, underscoring Europe's low birth rates and generous welfare state. These factors have weakened the continent and made it dependent upon immigrants, largely Muslims, to work and maintain the social benefits for the elderly non-productive social sector. The European "nanny state" has therefore played a central role in transforming Europe into "Eurabia." Even as many immigrants work to support the welfare state, however, many others become dependent on its services in ways that support the maintenance of state-subsidized enclaves that cannot assimilate to mainstream culture.

Thornton agrees with Steyn that Europe impedes the progress of immigrants is by lavishing welfare benefits on them, and further elaborates on the idea of "Eurabia" by drawing on Bat Ye'or's definition of the term: "Europe's evolution from a Judeo-Christian civilization, with important post-Enlightenment secular elements, into a post Judeo-Christian civilization that is subservient to the ideology of jihad and the Islamic powers that propagate it." Thus, again borrowing from Bat Ye'or, Europe is becoming a "civilization of dhimmitude" ([20], p. 90) — that is a civilization that is being subservient to Muslim rule. Thornton associates this condition with the decline of Christianity and Europe's failure to protect Western Christianity:

In the past, Europe's resistance to Islamic imperial ambition was fired by Christian faith... But having abandoned God and country, where will Europe find the spiritual resources to assert the rightness of the Western civilization Christianity helped to create, and fight back vigorously against those who wish to destroy it? ([20], p. 130)

In Thornton's account of the situation, secularism has created a politics void of religious conviction. In the absence of such conviction, the void is being filled by outsiders, hostile to Europe's unique religious heritage.

Intriguingly, this call to respect and protect Europe's Christian heritage finds an echo in Ayaan Hirsi Ali, herself an atheist. Hirsi Ali calls on Muslims to learn from and perhaps convert to Christianity, largely on account of modern, post-Enlightenment Christianity's superior treatment of religious dissenters.

I would by far rather live in a Christian than a Muslim country. Christianity in the West today is more humane, more restrained, and more accepting of criticism and debate. The Christian concept of God today is more benign, more tolerant of dissent. But the most important difference between the two civilizations is the exit option. A person who chooses to opt out of Christianity may be excommunicated from the Church community, but he is not harmed; his destiny is left to God. Muslims, however, impose Allah's rules on each. Apostates - people, like me, who leave the faith—are supposed to be killed ([16], p. 244). 
Hirsi Ali goes on to represent the involvement of Christian groups as perhaps the most crucial element in integrating Muslim immigrants and stopping the spread of radical Islam: "the clash of civilizations can be won through religious competition" ([16], p. 253).

Virtually all clash authors blame the West for lacking an appropriate strategy to deal with Muslim immigration; some also credit Muslims for having a dangerously coherent and effective strategy for infiltrating and asserting control over Western nations. William Wagner's How Islam Plans to Change the World is such a text. "In analyzing the Muslim strategy," Wagner states, "I have come to the conclusion that they have a three-pronged plan, which is as follows: jihad, daw'ah, and mosques." ([22], p. 12) According to Wagner, ${ }^{9}$ Islam becomes a threat and danger to the entire Western world and more importantly the Christian world, through their forms of proselytization, holy struggle and visibility. Wagner refers to Islam as a more or less unified and monolithic entity driven a drive for world domination: "In the search for world dominance, Islam will use truth as they understand it even if it conflicts with the Christian understanding of the term...Both the concepts of truth and fear have proven to be helpful in the overall Islamic strategy" ([22], p. 136, italics added).

Wagner dedicates a whole section of his book to the Islamic process of da'wah, or missionary work. One of his key concerns is that Christians are not competing vigorously enough with their Muslim counterparts.

These 'propagators' also carry the title of being daa'i. Sometimes these Islamic missionaries are fully funded.... Most likely, there are more daa'is preaching Islam in the West than there are missionaries in the Muslim countries preaching Christianity ([22], p. 42).

Though Wagner believes Christians are falling behind Muslims in the missionary enterprise, he remains convinced that Christian missions are morally superior to Islamic $d a$ 'wah, and dedicates an entire section within his text to the differences between the two religious approaches. One of the contrasts, for instance, is the greater Christian emphasis on charitable enterprises: "Christian Missions engages in the establishment of schools, hospitals and other benevolent institutions through cooperative methods" whereas "Islamic Da'wah stresses the construction of a mosque and then establishes its ministries" ([22], p. 44). This argument is pitched toward a relatively narrow audience and neglects to acknowledge the very extensive social services provided by Muslim revival organizations within Muslim-majority societies, but provides insight into how some Western Christian groups perceive interreligious relations within the context of the broader clash literature. ${ }^{10}$

\section{Failure of Muslim Immigrant Assimilation}

According to most clash authors, the failure to assimilate Muslim immigrants is the Achilles heel of Western civilization. The following quotes are illustrative:

William Wagner is a Baptist missionary and a professor of missions at the Golden Gate Baptist Theological Seminary.

10 Whereas most of the books cited in this paper were published by mainstream, non-religious presses, Wagner's text was produced by a Christian publisher dedicated to missionary work. Kregel Publishers, the publisher of Wagner's text, mission statement reads, "Our mission as an evangelical Christian publisher is to develop and distribute...trusted, biblically based resources that lead individuals to know and serve Jesus Christ." [23] 
[T]he spectacular failure of integration has brought some nations to the verge of social chaos and is leading others steadily in that direction ([24], p. 233).

The European failure to assimilate immigrants, as Timothy Garton Ash notes, may contribute to a "downward spiral which will be the curse of the national politics of Europe for years ahead...." Immigrant Muslim youth will increasingly become involved in Islamist extremism and outright terrorism, as happened in Madrid and London, thereby reinforcing native-born resentments and fears ([20], p. 45).

Almost without exception, contemporary clash authors paint a highly pessimistic picture of Europe's future, within which youth riots and incidents of delinquency and terrorism become ever more frequent.

Notably, clash authors steer clear of in-depth sociological analysis. Many thinkers who frame their analysis in terms other than those of the clash literature have argued that failures of integration are at least to some extent caused by barriers within European societies, which for decades desired guest workers for economic reasons and yet created legal as well as social obstacles to citizenship and full participation. Marginalization was therefore an outcome of specific policy choices, and inability to overcome job discrimination or invest appropriate resources. Clash authors, however, take the position that European nations have been far too accommodating. Laqueur, for example, argues that individual European citizens "had never been asked whether they wanted millions of new neighbors in their country... [and] about this very essential issue no one had ever consulted them" ([21], p. 171). As a result, European governments and societies found themselves in a position in which they were unable to provide guidance to newcomers but were instead "highly permissive." Social and political elites had lost their self-confidence; among the establishment, cultural and moral relativism rather than pride prevailed. Thus "newcomers to these countries were bound to gain the impression that prevailing laws and norms could safely be ignored" ([21], p. 172). Caldwell amplifies this point about ignoring prevailing Western norms and laws, stating that, "Islam in Europe is different." "Since its arrival half a century ago," Caldwell states, "Islam has broken or required adjustments to or rearguard defenses of a good many of the European customs, received ideas, and state structures with which it has come in contact." ([19], p. 13).

In addition to the general concerns about the failure of assimilation, the ghettoization of European Muslims is a major concern of clash thinkers. A number of authors stress that this condition is self-imposed by the Muslim community, and that religious leaders are particularly culpable. In these respects, Muslims are perceived as different from other ethnic communities:

Muslim newcomers apparently like to stick longer with their coreligionists than do other groups of immigrants, and they are encouraged by the preachers to do so. This is true even with regard to India, where there is more ghettoization than in Europe; even middle-class Muslims seem to be reluctant to leave the areas where members of their community live ([21], p. 42).

Muslim religious leadership has a vested interest in keeping Muslims in ghettos because it allows them to have better control in ensuring that "there is little, if any, contact between the faithful and the infidel." ([21], p. 206)

Of central concern is that areas of concentrated Muslim settlement become intensely conservative and resist cultural influences from the larger society. Most authors express concern that these new 
Muslim ghettos are "breeding grounds" with major demographic consequences, as reflected in high marriage and fertility rates. Because these rates are significantly higher than in the general population, the authors express grave concern Europe will be overwhelmed demographically from within, and not only in comparison to other world regions with rapidly growing populations.

It is against this backdrop of stated concerns that Steyn proclaims his thesis that, as central as America may be saving the world, concerted action is now necessary to save America. Calling his production "a doomsday book with a twist" ([17], p. 15), Steyn uses demographics to demonstrate Europe's inept and suicidal social politics, and to warn Americans about Europe's demise. He wants America to resist gradual "Islamization" that has penetrated the developed lands of Europe. In his view more Muslims in Europe correlates directly with more terrorism, honour killings, and polygamy, and inversely with individual and political freedom. To save America from such a fate, it must refashion its traditional role as the land of opportunity for newcomers, and avoid giving minorities too many rights. America, he proposes, is the West's last chance, and faces nothing less than an ideological war to preserve the "Western way of Life".

\section{The Problems of Political Correctness and Multiculturalism}

Another central theme of the clash literature is that Western elites have betrayed their mother culture, by indulging in excesses of self-criticism and self-doubt. These habits of thought and intellectual attitudes have led to an under-valuation of Western culture and to the rise of multiculturalism, which has been exploited by a Muslim adversary who benefits from pluralism without practicing it in relation to others. As the West now faces a powerfully motivated and implacable foe, clash authors assert, the West needs to recover faith in its past greatness and cultural heritage, as well as its willingness to engage in critique of other cultures.

Robert Spencer blames political correctness for current problems. Building on Bernard Lewis's judgment that Europeans "have no respect for their own culture," Spencer argues that political correctness has led to a double standard according to which the majority culture and religious traditions affiliated with this culture are subjected to scholarly and societal criticism:

Americans and Europeans...need to stop apologizing for all our forefathers allegedly and actually did wrong, and for the culture they built and remember what they did right, recognizing what Judeo-Christian civilization has brought to the world ([13], p. 3).

Rather than focus guiltily on historical misdeeds committed in the name of culture and religion, Spencer proposes, Western education and social commentary need to restore a sense of cultural pride or patriotism to collective consciousness. Without such a shift to a different way of being, Spencer believes that the West will ultimately lose the "War on Terror" ([13], p. 4).

Closely associated with this theme of political correctness is the idea of moral equivalency. Clash authors argue passionately in favour of Western moral superiority vis-à-vis Islam, and accuse Western elites of fostering a false perception that all religions and cultures are equal. Spencer, for example, argues that the present state of society and academia in the West has permitted the rise of a perception that Islam is "morally equal" to Christianity ([13], p. 1) — a perception with which he emphatically disagrees. Whereas an attitude of moral equivalency conceals the flaws of immigrant Muslim culture, 
respect for Western values demands an unwavering critique. Gilles Kepel elaborates on this point, specifically arguing that it was "the multicultural elite [who] was, almost without exception, allied with the Islamic right... [in] explaining away delinquency, suppressing reports of violence, standing up for the hijab, and so forth.” ([24], p. 212) Multiculturalism, this logic proposes, leads elites to stand up for the "other" even when the practices of this other are not acceptable in light of modern societal standards.

Bawer argues that Muslims pose a grave threat to liberal values in the Western countries where they live. The inability of Western leaders to uncompromisingly assert the priority of these values over the dictates of multiculturalism (which forces compromise with the Muslim immigrants' expectations), may be the factor that will ultimately result in the demise of Western liberal values. Bawer is especially concerned with what he perceives as the vulnerability of the right to free speech, and believes Western countries have taken too accommodating a response to Muslim offences during the past two decades, including rioting, death threats against critics, and murders of non-Muslims.

Free speech is in a crisis. To respond with the "accommodation" recommended by so many journalists, politicians, and intellectuals would be simply to submit to abandon freedom, embrace dhimmitude, and hope for the best from our new overlords ([15], p. 276).

For Bawer, multiculturalism is an evil that has forced Westerners into complacency with foreign cultural norms. It has blinded intellectuals to the threat that Islam poses to Western democracy, while simultaneously empowering Muslim immigrants and allowing them to resist adaptation to the ideals of the Enlightenment. To put the matter in even stronger terms, it has enabled Muslims to wage cultural warfare against the West from within the heart of Western societies. In Bawer's view, Muslims living in the West are engaged in a "cultural jihad" and will stop at nothing to bring the West into the "House of Submission", or "Dar al-Islam" ([15], p. 3). Bawer alleges that "the pernicious doctrine of multiculturalism" motivated non-Muslims to support Muslims in targeting Salman Rushdie, as multiculturalism "teaches free people to belittle their own liberties while bending their knees to tyrants... which... has proven to be so useful to the new brand of cultural jihadists that it might have invented Osama Bin Laden himself" ([15], p. 5).

A similar polemic against multiculturalism appears in Ibn Warraq's Why I am Not Muslim. According to Ibn Warraq, multiculturalism has lowered cultural defenses and enabled newcomers to make excessive demands. He equates multiculturalism with one or two attitudes with respect to human values - a false universalism or a harmful relativism:

The implications of Muslim demands on the wider British are enormous. Unless great vigilance is exercised, we are all likely to find British society greatly impoverished morally, and all the gains, social and moral, may well be squandered in an orgy of multicultural liberalism ([18], p. 353).

Multiculturalism is based on some fundamental misconceptions. There is the erroneous and sentimental belief that all cultures, deep down, have the same values; or if these values are different, they are equally worthy of respect. Multiculturalism, being the child of relativism, is incapable of criticizing cultures, of making cross-cultural judgments. The truth is that not all cultures have the same values, and not all values are worthy of respect ([18], p. 356). 
At the core of this argument is the contention that Muslim values overlap very little with Western liberal values, and that multicultural tolerance is one of the central factors perpetuating certain practices that are especially problematic from a Western liberal point of view. Rather than an attitude of respect and dialogue which invites reciprocity and coexistence, Ibn Warraq sees in multiculturalism and inability to engage in critical thinking, as well as a racism of low expectations: "Multiculturalists are incapable of critical thought, and in a deep sense are more racist than the racists they claim to fight" ([18], p. 354).

Bruce Thornton's Decline and Fall embellishes on this theme of multiculturalism as a key causal factor preventing assimilation. Thornton's overarching thesis is that Europe is becoming "Eurabia" due to "cultural toxins" imported by Muslim immigrants. This process is facilitated by a doctrine of multiculturalism that permeates the thinking of Western elites. The essence of multiculturalism is not the call to recognize and respect the value and contributions of other cultures, something that he believes the West has been doing for centuries. Rather, openness to the cultural 'other' and willingness to criticize one's own ways has degenerated into a naïve idealization of the non-Westerner and a corresponding hatred of the West ([20], p. 96).

Thornton explains that modern multiculturalism in the West began with Europeans admiring the "noble savages" they encountered, including American Indians, South Sea Islanders, Africans, and Arabs. These peoples seemed to embody a simpler, more humane existence that the West had abandoned in its pursuit of power and profit. This is seen in the Romantic complaints such as the following by Wolfgang von Goethe in 1828 :

We other Europeans are ailing. Our styles of life are far from the healthy state of nature, and our social relations lack charity and benevolence. ... I often wish I were one of those so-called savages born in the islands of the South Seas, so that at least once I could savor human experience in its purity, without some artificial aftertaste ([20], pp. 97-98).

Thornton contends that such attitudes have dominated the art and literature of the West for the last two centuries, eroding cultural certainty and self-confidence.

Another key factor in Thornton's critique of elite attitudes that have undermined the West is Marxism. He notes that, like the Romantics, Marxists similarly complained about the West in their writings on the destructive effects of industrial capitalism, which Marx himself represented as a system which had replaced the humane, organic relations between people with the alienating, dehumanizing power of the contract, private property, wage labour, and the profit motive ([20], p. 98). Such assumptions, Thornton alleges, caused the West to give more credit to pre-capitalist non-Western societies than was warranted. Idealization of the non-West also found reinforcement in later Marxist analyses of imperialism and colonialism. This led to the idealization of the Third World as "history's instrument for transforming the wicked West; because of this, resistance to immigration, demands that immigrants assimilate to their new homes, and expressions of national pride have all become 'fascist', tainted with Nazi racism and the Holocaust" ([20], pp. 99-100).

Echoing many other conservative thinkers and clash theorists, Thornton argues that Western intellectual elites have destructively wedded themselves to "self-hating" ideas. Leftists, he believes, have used naïve idealizations of the Third World as the basis for pursuing the liberation of the oppressed, while ignoring the very brutal imperialist ambitions of the Soviet Union as well as the 
current expansionist ambitions of jihadists. The currently reigning mode of thought is "Third Worldism," the doctrine that "every Westerner is presumed guilty until proven innocent" ([20], p. 100). The way of thinking is the product of a combination of noble-savage idealism and Romantic discontent with Marxist-Leninist theorizing and post-Marxist multiculturalism. The result is a suicidal self-hatred among many Westerners, who, convinced of their guilt, do not have the cultural resources for defending their way of life: "These days, the successor of Europe is Eurabia" ([20], p. 101).

Because of multiculturalism, then, Muslim immigrants have been allowed to perpetuate their cultures no matter how alien to the values of western civilization even as the European nations make it difficult for those who wish to assimilate. Immigrant communities are allowed to create their own standards of behavior, educational curricula, social mores, and public practices, indulgences not allowed native born-citizens of host countries ([20], p. 101).

Multiculturalism, then, creates too much space for difference. To back up this claim, Thornton uses the following examples:

- In Sweden, the legal age of marriage is 18 , but for immigrants there is no minimum age.

- Turkish and Pakistani immigrants in Germany are exempted from the usual intrusive procedure that a German who wishes to marry someone not from an E.U. member state has to undergo in order to prove that the relationship is legitimate, on the assumption that their marriages are arranged.

- In France, public swimming pools are segregated by sex to appease Muslim sensibilities.

- Some British retailers have stopped selling mugs that depict the character Piglet because Muslims find pigs offensive.

- Burger King's chocolate ice cream swirls were banished in some places because they reminded Muslims of Arabic writing.

- After the murder of Theo Van Gogh, Dutch schoolchildren were not allowed to wear Dutch flags on their backpacks lest Muslims find them provocative ([20], pp. 101-02).

Thornton categorically rejects the notion that at least some bias towards Muslim immigrants is based on prejudice and ignorance. He characterizes "Islamophobia" as a new thought-crime, a variation on the "racist" charge used by multiculturalists to forestall criticism or silence those who speak of uncomfortable facts. Such oversensitivity, he proposes, illustrates how far the European establishment has gone in abandoning its own values such as freedom of speech and respect for truth in order to appease a vocal minority ([20], p. 103). Thornton rejects charges of Islamophobia for his own beliefs, and maintains that many of the supposedly false prejudices about Islam are true. He maintains, for example, that Islam is responsible for the mistreatment of women and for intolerance towards other faiths ([20], p. 104).

A core theme of the clash literature is that, rather than accommodate Muslim identity, Europeans and Westerners need to assert Western identity. Western eagerness to be politically correct results in efforts to accommodate Muslims at any cost. It gives Islam an advantage and adversely affects Western policy and the Western way of living. Whereas a focus on accommodation and mere integration contributes to an erosion of Western identity, a reemphasis on assimilation might help to correct a creeping tendency toward Muslim domination ([17], p. 60). Steyn frames the reassertion of a 
more exclusive Western identity as a matter of "Cultural Will": the Western majority culture needs to use the power it still has, and demonstrate that it is not weak.

\section{Women's Emancipation as a Focal Point}

In the clash literature, the status of Muslim women is construed both as a major defect in Muslim culture and as a potential wedge issue in the struggle between Islam and the West. Muslim women are presented as inexcusably oppressed, in a manner that faithfully reflects fixed and inflexible Islamic beliefs. Clash authors see these beliefs as the primary determining factor in a number of negative cultural dynamics, particularly abusive patriarchal authority, submissive and oppressed women, and the perpetuation of dangerous Muslim countercultures characterized by resentment and rapid population growth. They therefore aspire to amplify the voices of the most aggrieved and confrontational voices among Muslim or ex-Muslim women, who are represented as reliable interpreters of the overall Islamic experience.

Ayaan Hirsi Ali, often selected by other clash authors as the most authoritative voice on the oppression of Muslim women, represents the plight of women under Islam in starkly negative terms. Her portrait offers minimal nuance, and takes no note of variation in Muslim women's experiences in accordance with interpretive beliefs, geography, culture, or social class. "The will of little girls", she states, "is stifled by Islam".

$[B] y$ the time they menstruate they are rendered voiceless... they are reared to become submissive robots who serve in the house as cleaners and cooks... they are required to comply with their father's choice of mate and after the wedding their lives are devoted to the sexual pleasures of their husband and to a life of child-bearing... their education is often cut short when they are still young girls, and thus as women they are wholly unable to prepare their own children to become successful citizens in modern, Western societies. Their daughters repeat the same pattern ([16], p. xvii).

Nowhere in this account can one find acknowledgement of facts, which do not fit stereotypes, such as the dramatic growth of women's presence at university campuses (where they sometimes outnumber Muslim men) and in professions. Hirsi Ali's characterization is entirely consistent with Robert Spencer's hostile representation of Islam as a faith that in its immutable essence promotes gender inequality and violence towards women through genital mutilation, honour killings, stoning adulteresses, and holding women responsible for being raped ([13], p. 35). Neither author seeks to educate the reader about the non-universal character of such practices, or about Muslim voices who argue against them on an Islamic basis.

A reasonable argument can of course be made that traditional forms of Muslim patriarchy pose barriers to the advancement of Muslim women and to the successful integration of Muslim communities within Western societies. Hirsi Ali underscores this issue, albeit in a manner that equates the essence of Islam with specific historical practices and interpretations, and presents religion as an overwhelmingly negative factor:

I believe that the subjection of women within Islam is the biggest obstacle to the integration and progress of Muslim communities in the West. It is a subjection committed by the closest of kin in the most intimate place, the home, and it is sanctioned by the greatest figure in the imagination of Muslims: Allah himself([16], p. 160). 
As a formerly Muslim informant testifying to her own experience of oppression by family members in the name of religion, Hirsi Ali has produced a raw account that has a powerful impact on North American and European readers. Most Muslim feminists, however, would object strongly to her rhetorical equation of cultural pathology with the essence of a religion, articulated in a manner that seems intended to provoke outsiders to fight for the souls of Muslim women. Hirsi Ali argues that Western feminists should take on the plight of Muslim women and make it their own cause. There are three goals they must aspire to: ensuring that Muslims girls are free to complete their education; helping them to gain ownership over their own bodies and sexuality; and making sure that Muslim women have the opportunity to enter the workforce and stay in it, without restraints. Western feminists might also be at the forefront of a campaign to educate Muslim men on the importance of Muslim women's emancipation ([16], p. xix).

Although it may be an exaggeration to describe this approach to Islam and Muslims as "kill the Muslim, save the woman," most writers of Western-sourced clash literature regard fighting to liberate Muslim women as a critical front in the culture war between Islam and the West. They are profoundly impatient with "mainstream" voices of reform and moderation within Muslim communities, and give disproportionate attention to individuals who have written off Islamic reform movements and denounced Muslim culture categorically. The predominant tendency is to use the "status of women" issue as a key talking point in generalized critiques of Islam, with the goal of demonstrating the superiority of contemporary Western norms.

\section{Analysis}

Despite variations in emphasis and in the precise structure of arguments, the clash literature manifests a number of consistent tendencies that express the profound anxiety of many authors with respect to Islam, and that signal serious challenges for protagonists of intercultural dialogue and coexistence. First, the literature as a whole appears to be driven by deep-seated identity insecurity, not just in relation to an "intrusive" and seemingly monolithic Islam that is wholly "other," but also in relation to an idealized but now receding West that is being threatened from within by what the authors perceive a corrosive over-extension of their civilization's own ethos of critical reason. The remarkably broad generalizations and sharp dichotomies used in the literature are best understood not just as efforts to define an enemy, but also as attempts to recapture or define an "authentic" identity that has become internally contested. Thus, the arguments are not just about Islam, but also about the West. Second, in their critiques of Islam the clash authors rely heavily on extrapolation from past demographic data trends and from provocative incidents, with only limited consideration of complex causal factors that might provide a much richer context for understanding the phenomena in question. In this sense the literature appears to be more alarmist than analytical in nature and intent. Third, to the extent that the authors surface some genuinely problematic issues within Muslim cultures (immigrant and otherwise) and Islamic-Western relations, the insistence on polarization and "winning" manifested by their writings actively pushes against collaborative solutions predicated on dialogue and relational engagement. 


\subsection{Arguments Rooted in Insecure Identity}

The arguments of clash authors manifest not just a profound fear of Islam, but also a powerful anxiety about threats to the future of "the West" that predates current controversies. In other words, the clash literature's call to arms against Islam and Muslim immigration is not simply a matter of Islamophobia, though certainly the discourse is permeated with deep distaste for all things that purport to be Islamic. Rather, is it also an expression of a longstanding debate about what the West is and should be. The fact that "the West" is so consistently represented in unproblematic, uncontested, essentialized terms - even as traitorous or suspect Western tendencies such as multiculturalism, Romanticism, or leftism are denounced - is itself a signal that, whatever else concerns the clash authors, they are fundamentally engaged in Western identity politics. In this sense, Islam enters the equation both as a substantive concern (there is no reason to doubt the genuineness of their fears) and as a foil, a useful "other" for defining what the "self" ought to be or not be. The clash authors' simplistic, essentialized, and almost entirely negative representations of Islam, therefore, serve the purpose of defining basic us/them distinctions that have an import which transcends intercultural relations.

In a very real sense, the clash authors' are deeply insecure about and uncomfortable with what the West concretely is and has become: hybrid, diverse, contested, culturally plural, and religiously diverse. This discomfort has been a long time in the making and is not new. The issue of Islam brings this discomfort to the surface, producing discourse that seeks to save what the authors fear they are losing, and to that end seeks to draw sharp dichotomies that reassert cultural boundaries and amplify debate about what it means to be "Western." The result is a discourse that privileges an idealized Western and European culture, juxtaposed with willfully undifferentiated representation of Islam as a static, unchangeable, and threatening adversary culture. Unreflective use of the term "Eurabia" manifests a sharply reductionistic tendency to equate Islam as a whole (a faith that spans continents and cultures) with Arabia and Arabia with salafist extremism.

The diversity within both of these "macro-identities" is purposefully downplayed and the relevant scholarly literature on this diversity is ignored. Europe is presented as the human Christian civilization that gave birth to skeptical humanism, and Islam as a universal, authoritarian, misogynist ideology without significant internal conflicts, schisms, and interpretive or legal debates. In seeking to galvanize Europeans against Islam and Americans against the European response to Islam, the authors seek to call Westerners back to fundamentals and undermine adversaries within their own context. Some readers may detect notes of envy in clash authors' characterizations of strong Muslim identities and doctrinal certitudes. Caldwell, for example, emphasizes the strength, confidence, and cohesion of Muslim culture, which in his view is an inherent threat to a more loosely anchored and "malleable" European culture ([19], p. 349). This imbalance, he believes, works to the detriment of Europeans, which are easily overwhelmed by strong immigrant cultures.

To be sure, certain issues more salient for some clash authors than for others. For some, security and terrorism remain the preeminent issues, while, for others, a greater sense of motivation may arise from a sense of threats to individual freedom (including freedom from religion) or from a sense that traditional allegiance to Christianity or Judeo-Christian civilization has been betrayed by intellectual elites. In the issue of Islam, however, clash authors find common cause and a push to renegotiate among themselves a "pure" Western identity that is in many respects a new construction. In the 
process there is an opportunity and a need to affix blame to those who have let the "barbarians" through the gates.

Insofar as the clash literature is not only about "them" (Muslims) but also about "us" (people of the West and their existential discomfort with a changing world), the genre is arguably more symptomatic than diagnostic. Clash authors manifest great concern to draw lines and refuse identity negotiations with the deemed recalcitrant "other," and show very little interest in developing a nuanced, complex understanding of who that "other" actually is. Notably absent is the increasingly voluminous scholarly literature on Muslim negotiations with modernity, and only a few select scholars who deal with things Islamic are deemed trustworthy. Caldwell, for example, dismisses discussion of Muslim diversity "pleasing glibness," and like other clash authors characterizes Islam as a primordial religion impervious to outside influences and change. Thus, those who seek points of contact and shared values - let alone a reflection of the self in the other - are portrayed as outlandishly naïve.

\subsection{Reliance on Extrapolation, with Minimal Context}

In playing the role of Cassandra vis-à-vis a growing Muslim threat, clash authors repeatedly employ a style of reasoning based on simple extrapolation from past trends and generalization from specific, emotionally gripping incidents. The approach treats cultural and religious entities as static vectors rather than as dynamic communities that can change in response to new circumstances and relationships, and actively selects from the most disturbing of current events to give meaning to changing demographic realities.

Superficial use of demographic data is a clear liability of the clash literature, even when the figures themselves do speak to dramatic new tendencies in European societies. Immigration rates and differences in birthrates matter, and it appears certain that Islam will henceforth (albeit not for the first time in history, given centuries of Muslim presence in Spain and in Southeastern Europe) be a visible part of the European experience. The notion that this European experience will not or cannot have an impact on the way Muslims experience and express Islam, however, is as poorly founded as the notion that Muslim culture is immune to the sort of demographic transition that typically occurs in populations subsisting in industrial and post-industrial economic milieus. Anyone with close experience of young Muslim women pursuing university degrees, for example, is likely to discover that these women have professional and life aspirations that are highly similar to those of their non-Muslim counterparts. Simply put, "Islam" and "Muslims" are not categories that place human beings outside the larger continuum of human experience, and the notion that Muslims cannot adapt or will inevitably overwhelm others appears not just ill-founded but also prejudicial.

Another troubling tendency in the clash literature is its frequent exploitation of disturbing events for emotional impact. Clash authors over-select such events in their narratives and overgeneralize their representativeness, in ways that are clearly intended to arouse fear and anxiety in the reader. At the same time, they pass over incidents of violence or intimidation directed at Muslims in silence. While such selectivity and desire for emotional impact may be inevitable features of the journalistic style in which these books have been written, there is nonetheless a telling absence of humanizing portraits in the clash literature, despite the reality that "ordinary", non-threatening Muslims are much easier to encounter than extremists bent on violence or wedded to grandiose agendas. By over-selecting the 
negative, remaining silent about abuses committed against Muslims, and putting events and statistics in the most alarming context possible, clash authors seek to influence their audience in ways that are more alarmist than analytical.

This can be seen in Steyn's use of data from a poll conducted by the Times of London. Steyn conveys that seven percent of Muslims questioned agreed that suicide bombings of civilians could be justified in certain circumstances. Steyn interprets this to mean that significant numbers of Muslims are radical extremists. However, he does not explain how many people were polled, and to what extent those polled could represent the larger European Muslim population. He also ignores other data which reveals that the percentage of people who are willing to justify intentional bombing of civilians under "some circumstances" is roughly comparable in Western and Muslim contexts. By cherry-picking facts and ignoring those that do not fit the picture, any nation or religious group can be portrayed in a dark light.

A hallmark of quality analytical literature is that it is capable of confronting problematic issues and behaviour patterns in ways that probe beneath the surface, generating insights into circumstances and motivations in a way that does not obscure common humanity ore foreclose the possibility of constructive change. The clash literature falls short on these counts, by denigrating the search for drivers of extremism (an exercise that is deemed a form of capitulation), downplaying social class and social justice considerations, and ignoring the significance of prejudice, discrimination, and social exclusion. While there is no need to place all responsibility on host societies and governments or to hold immigrant communities blameless in instances where maladaptation is evident, the clash literature is deeply problematic in a host of ways: it ignores useful sociological insights, it vastly overgeneralizes about the other, it discounts the relevance of dialogue, and substitutes cultural reassertion for wide-ranging examination of policy options.

\subsection{Insistence on Polarization over Relational Engagement}

Ultimately, the clash literature identifies some genuine problems with Muslim integration in the West as well as in contemporary Muslim-majority cultures, but subverts critical reflection on ways in which "the West" is either implicated in these problems or capable of positive engagement with constructive forces within Muslim communities and cultures. The worldview of clash authors is not relational, and seeks no meaningful relationship with the Muslim other. The approach is profoundly non-dialogical and polarizing, with an emphasis is on winning rather than on transforming the conflict.

To an extent, the clash literature manifests continuity with Cold War narratives, albeit but with a new religio-cultural twist. Like post-9/11 Europe and North America, the Cold War world was one of polarization and ideological competition, within which complex world events were often viewed through lenses of East-West competition rather than in relation to complex local circumstances and realities. Then as now, the loyalty of Europe to the Western cause was suspect in the eyes of many Cold War protagonists, and the successors of these leading Western Cold War thinkers are now among the ranks of those seeking to understand the world in light of a new polarity.

If there is to be hope of transcending this polarity and creating a world in which "Islam" and "the West" are not mutually exclusive categories, relational engagement and dialogue are indispensable. It is not enough for Western pundits to speak about or even "to" Muslims, and dysfunctional to try to resurrect a past civilization based on mythical notions of purity. New forms of engagement are needed, 
and Western protagonists of such engagement need not embrace "relativism" to pursue it. Indeed, interlocutors that were truly confident in such putative Western values as reason, freedom, and equality would see no need to mythologize Western history (which, after all, has been full of both contradictions and progressive struggles to overcome them) or deny the existence of Muslims whose values overlap with those held by people in the West. Insofar as the clash literature manifests a certain lack of confidence in the West's greatest virtues, particularly in the domains of self-critique, dynamic reinvention of the self, and free-spirited of exploration, it offers few starting points for the needed cross-boundary engagement.

\section{Conclusions}

This essay has provided an overview and critique of a literature that is not often engaged by university-based scholars. There are reasons for this: most of the literature is not academic in nature, ignores relevant scholarship, and traffics in oversimplifications and polarizations that few scholars embrace. Nonetheless, precisely because this literature has wide circulation and plays a powerful role in constituting political discourse (as is evidenced by preemptive anti-sharia campaigns in the United States and the formation of anti-immigration parties in Europe), critical examination is needed.

While the term "clash literature" may seem novel or ambiguous, the term has been used here to refer to writings that articulate a number of consistent themes. First, these writings present a stark worldview in which Western liberalism is locked in a dangerous conflict with Islamic authoritarianism, with highly consequential developments currently unfolding in Europe. These events put the future of the West in question, despite its unassailable moral superiority in relation to Islam and non-Western cultures. Second, clash authors maintain that this struggle is rendered all the more difficult by what they judge to be an absence of genuinely moderate, progressive, and conciliatory tendencies within the global Muslim community. Islam demands conformity, they argue, and even "moderate" Muslims identify with some of the same grievances articulated by "extremists." Third, culture-clash thinkers place a very strong emphasis on threatening demographic trends associated with Muslim immigration; these trends have been made possible by (and accelerate) a loss of faith in the Judeo-Christian tradition, and make the demise of the West distinctly possible, to the extent that Europe may already be "lost." Fourth, clash authors seek to reinforce their arguments by claiming that resistance of Muslim immigrants to assimilation is a static and multi-generational condition. Muslims are unlike most other immigrants, and operate by values, which are alien to the contemporary Western tradition. Fifth, they maintain that the West has long been in denial with respect to these growing problems, on account of pervasive political correctness and the salience of multiculturalist sensibilities. Simply put, the West is in in crisis because of the disloyalty of its own intellectuals. Those responsible for economically based decisions to permit large-scale immigration, to satisfy demands of industry for guest workers and cheap labour, are not targeted with comparable accusations. Finally, clash authors propose that women's emancipation is one of the most fundamental wedge issues between Islam and the West, and needs to receive a strong focus from those seeking to stave off a Muslim takeover of Europe and push for victory in the protracted cultural war between civilizations.

While critiques of these sweeping, pessimistic assumptions are not difficult to identify, this article has sought to draw particular attention to three crucial issues raised by the clash literature. First, I have 
argued that, while these writings are intensely Islamophobic and purvey hostile stereotypes, they also reveal a great deal of insecurity with respect to Western identity. The literature's deeply problematic essentializations and generalizations warrant strong criticism, but there is also a need for awareness that the popular success of this literature stems not just from prejudice and lack of knowledge but also from deep-seated anxiety and insecurity. Old visions of what Europe and "the West" should be clearly to not fit the present reality, and there is a vacuum of compelling visions for how these identity structures might evolve in the future. The clash literature seeks to fill this vacuum with disturbing, reactionary visions that conveniently stigmatize a particular identity group.

The second and third lines of critique relate to the types of argument used and to the authors' proclivity for polarizing relationships that might possibly be bridged by other means. Clash books thrive on pessimistic extrapolation of demographic trends without a deep analytical investigation of underlying factors, and rush to conclusions about entire population groups based on specific cases of delinquency and violence. Their thesis that Muslims are difficult if not impossible to assimilate closely mirrors accusations directed against Catholic immigrants to the United States during the late nineteenth and early twentieth centuries. This pattern provides cause for reflection. Polarization and sharpening social conflict appears to be a primary goal of the genre, which actively dismisses dialogue and the value of relational engagement.

The clash literature demands a response-preferably a response that is not just a reaction or an application of pejorative labels to the authors, most of whom are doubtlessly sincere in their fear of Muslims, even when capitalizing on popular moods and anxieties for commercial gain. What is needed is a response that makes the complex nature of Islam-West relations more easily intelligible, and that liberates creative imagination by telling new stories. Scholars as well as journalists need to find ways to give voice to people who thrive at the intersection of cultures, who are not afraid, who honour the past but do not cling to it, and who are willing to learn and expand their sense of identity and belonging through encounters with otherness. A reaction to the clash literature that merely stigmatizes the clash theorists is a reaction that addresses symptoms but not the deeper problems. To give substance to ideas of dialogue and coexistence, authors need to dispense with simplistic dichotomies and dualisms, and with efforts to make fortresses out of Europe, North America, or any other cultural region. A scholarship that is itself dialogical and engaged might offer a stronger remedy, by surfacing latent visions, articulating "unstoried" experiences, and demonstrating that the points of intersection among cultures are sites not just of friction, but also of mutual learning, shared discovery, and common humanity.

\section{Conflicts of Interest}

The author declares no conflict of interest.

\section{References}

1. Said, Edward. Orientalism. New York: Vintage Books, 1979.

2. Esposito, John, and Kalin, Ibrahim, eds. Islamophobia: The Challenge of Pluralism in the 21st Century. New York: Oxford University Press, 2011. 
3. Lean, Nathan. The Islamophobia Industry: How the Far Right Manufactures Fear of Muslims. London: Pluto Books, 2012.

4. Sheehi, Stephen. Islamophobia: The Ideological Campaign against Muslims. Atlanta, GA: Clarity Press, 2011.

5. Lockman, Zachary. Contending Visions of the Middle East: The History and Politics of Orientalism. Cambridge: Cambridge University Press, 2009.

6. Saunders, Doug. The Myth of the Muslim Tide: Do Immigrants Threaten the West? Toronto: Knopf Canada Publications/Random House of Canada Publishers, 2012.

7. Keen, Sam. Faces of the Enemy: Reflections of the Hostile Imagination. San Francisco: Harper \& Row, 1986.

8. Montville, Joseph. "The Healing Function of Political Conflict Resolution." In Conflict Resolution Theory and Practice: Integration and Application. Edited by Dennis J.D. Sandole and Hugo van der Merwe. New York: Manchester University Press, 1993, pp. 112-27.

9. Moses, Rafael. "On Dehumanizing the Enemy." In The Psychodynamics of International Relationships: Volume I: Concepts and Theories. Edited By Vamik D. Volkan, Demetrios A. Julius and Joseph V. Montville. Lexington, CT: Lexington Books, 1990, pp. 111-18.

10. Nomani, Asra. Standing Alone in Mecca: An American Woman's Struggle for the Soul of Islam. San Francisco and New York: HarperSanFrancisco, 2005.

11. Sharify-Funk, Meena. Controversies, Clichés, and Conversations: Islam, Muslim Women, and the Negotiation of Identity in Contemporary North America. Forthcoming.

12. Safi, Omid. "Not conducive to the public good: American islamophobes barred from the UK." Religions New Service, 26 June 2013. http://omidsafi.religionnews.com/2013/06/26/notconducive.

13. Spencer, Robert. Religion of Peace?: Why Christianity Is and Islam Isn't. Washington, DC: Regnery Publishing Inc., 2007.

14. Spencer, Robert. "About Robert Spencer." Available online: http://www.jihadwatch.org/aboutrobert-spencer.html (accessed on 6 February 2013).

15. Bawer, Bruce. Surrender: Appeasing Islam, Sacrificing Freedom. New York: Doubleday Publishers, 2009.

16. Hirsi Ali, Ayaan. Nomad: From Islam to America. New York: Simon \& Schuster Publishers, 2010.

17. Steyn, Mark. America Alone: The End of the World as We Know It. Washington, DC: Regnery Publishing Inc., 2008.

18. Warraq, Ibn. Why I am Not a Muslim. New York: Prometheus Books/Random House Inc., 2010.

19. Caldwell, Christopher. Reflections on the Revolution in Europe: Immigration, Islam, and the West. New York: Doubleday Publishers, 2009.

20. Thornton, Bruce. Decline and Fall: Europe's Slow-Motion Suicide. New York: Encounter Books, 2007.

21. Laqueur, Walter. The Last Days of Europe: Epitaph for an Old Continent. New York: Thomas Dunne Books/St. Martin's Press, 2007.

22. Wagner, William. How Islam Plans to Change the World. Grand Rapids, MI: Kregel Publishers, 2008. 
23. "Kregel Publications." Kregel Publications. Available online: http://www.kregel.com/ME2/ Default.asp.authors (accessed on 10 February 2013).

24. Kepel, Gilles. The War for Muslim Minds: Islam and the West. Cambridge, MA: Belknap Press of Harvard University Press, 2004.

(C) 2013 by the author; licensee MDPI, Basel, Switzerland. This article is an open access article distributed under the terms and conditions of the Creative Commons Attribution license (http://creativecommons.org/licenses/by/3.0/). 